\title{
KONSEP IQRA' PADA ANAK USIA DINI
}

\author{
Hikmatur Rahmah
}

\begin{abstract}
The command to iqra in Qur'an as the first revelation is a concept of command to read. In this context, the word iqra (read) means an activity to get to know, comprehend, analyze, observe, and learn all things in life. It could also be specifically interpreted as reading books. The book here is not limited to Qur'an, but each and every beneficial thing. Children are blank slates of human that must be introduced to books and reading. However, it is obvious that there is a difference in teaching reading to early childhood and to adults. Reading is an enjoyment for children, full of pictures and colors, laughter and happiness. The essence of children is to be engaged in new things. So, reading is a way to introduce numerous new things to early childhood.
\end{abstract}

keywords: Qur'an, reading, early childhood.

\section{PENDAHULUAN}

Iqra' sebuah perintah suci yang pertama kali Allah turunkan kepada NabiNya Muhammad Saw. Iqra' dalam bahasa arab adalah fi 'il amr, atau kata kerja perintah yang bermakna bacalah. Tetapi dalam penafsirannya kata Iqra' bukan sekedar proses membaca, tetapi juga proses melihat, menelaah, mengkaji, meneliti dan lainnya. Ini menjadi menarik, karena perintah pertama yang Allah turunkan bukanlah perintah berimanlah, atau bersaksilah atau yakinilah, tetapi bacalah. Tentunya ini menjadi dalil dan bukti bagaimana membaca adalah hal yang sangat penting dalam beragama dan menjalani kehidupan di muka bumi ini.

Iqra' pada anak, bukanlah sekedar mengajarkan buku iqra' pada anak, atau mengenalkan huruf-huruf Al-Qur'an sejak dini. Tetapi lebih dari itu, iqra' adalah sebuah konsep pendidikan literasi pada anak sejak dini. Iqra' adalah sebuah konsep pengembangan aspek kognitif anak sejak dini. Iqra' mengajarkan kita para pendidik dan orangtua, untuk mengenalkan anak pada agama dan 
dunianya dengan berbagai aktivitas yang dilakukan antara anak dan orangrtua. Iqra' adalah proses tumbuh kembang anak yang alami, dalam melihat, menelaah dan mencari tahu apa yang ada di sekelilingnya. Iqra' adalah proses mengenal Allah sebagai tuhan dengan mengenal ciptaannya. Secara simpel, iqra' bismi Robbika adalah kosep mengajarkan anak membaca bismillah dalam memulai sesuatu.

\section{PEMBAHASAAN}

\section{A. Perintah Iqra' dalam Pendidikan Anak Usia Dini}

Iqra' adalah perintah sekaligus wahyu pertama yang diturunkan Allah Swt. kepada Nabi Muhammad Saw. melalui malaikat Jibril di gua Hira pada 17 Ramadhan tahun 610M di malam hari, yaitu tepatnya di dalam Q.S. Al-Alaq: 1, Allah Swt. berfirman:

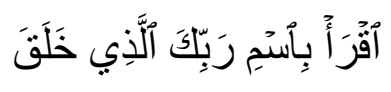

Terjemahnya:

Bacalah dengan (menyebut) nama Tuhanmu Yang menciptakan(Q.S. AlAlaq:1)

Iqra' Merupakan bentuk fi'il amar (perintah), ia berasal dari akar kata qoro'a yang pada awalnya mengandung arti menghimpun. Kata tersebut dapat diartikan juga dengan menyampaikan, menelaah, membaca, mendalami, meneliti mengetahui ciri-ciri sesuatu. ${ }^{1}$

Imam Muhammad Abduh memahami perintah disini bukan sebagai beban tugas yang harus dilaksanakan (amr taklifi) sehingga membutuhkan objek, tetapi ia adalah amr takwini yang mewujudkan kemampuan membaca secara aktual pada diri Nabi Muhammad Saw. Pendapat ini dihadang oleh kenyataan bahwa setelah turunnya perintah ini pun Nabi Muhammad Saw. masih tetap dinamai Al-Qur'an sebagai ummy (tidak pandai membaca dan menulis), di sisi lain jawaban Nabi kepada Jibril ketika itu, tidak mendukung pemahaman tersebut.

\footnotetext{
${ }^{1}$ Quraish Shihab, Tafsir Al-Misbah, XV, (Jakarta: Lentera Hati, 2012), 454.
} 
Kalau ditinjau dari perspektif kebahasaan, jika ada perintah yang tidak disebutkan objeknya, maka ia menunjuk pada sesuatu yang bersifat umum, artinya sesuatu yang bisa dijangkau oleh kata tersebut, seperti jagat raya, manusia, tumbuhan dan lainnya. Dengan demikian menjadi fokus pada ayat tersebut adalah pembacaan yang dilandasi atas nama Tuhan agar menjadikan kesadaran akan kefakiran diri di hadapan Allah.

Syeikh Abdul Halim Mahmud yang menulis bukunya Al-Qur'an fi Syahr Al-Qur'an bahwa dengan kalimat Iqra' bismi Rabbik, Al-Qur'an tidak sekedar memerintahkan untuk membaca, tapi "membaca" adalah lambang dari segala apa yang dilakukan oleh manusia. Baik yang sifatnya aktif maupun pasif, kalimat tersebut dalam pengertian dan semangatnya ingin menyatakan "bacalah demi Tuhanmu, bergeraklah demi Tuhanmu, bekerjalah demi Tuhanmu". Demikian juga apabila anda berhenti bergerak atau berhenti melakukan sesuatu aktivitas, maka hendaklah hal tersebut juga didasarkan pada bismi Rabbik sehingga pada akhirnya ayat tersebut berarrti "Jadikanlah seluruh kehidupanmu, wujudmu dalam cara dan tujuannya, kesemuanya demi karena Allah". ${ }^{2}$

Konsep iqra' ini, kita dapat terapkan pada pendidikan dan pengasuhan anak dengan berbagai cara, diantaranya:

1. Kenalkan berbagai hal baru pada anak

Anak adalah pembelajar ulung, otaknya berkembang begitu cepat di usianya yang dini, maka penting bagi kita mengenalkan berbagai hal pada anak dalam proses perkembangan otak dan daya pikirnya. Misalnya: Kenalkan ia tentang Tuhannya, dengan senantiasa menyebut asmaNya di telinganya, memperdengarkan ayat-ayatNya dalam kesehariannya dan membawanya melihat alam dan isinya untuk mengenalkan betapa Maha Besar Tuhannya.

Kenalkan ia tentang berbagai macam suara hewan di sekitarnya, kenalkan ia tentang ragam warna bunga yang lagi booming selama pandemi ini. Kenalkan ia tentang rasa dan karsa. Dan banyak hal yang kita harus kenalkan pada anak, agar ia tumbuh dengan pengetahuan yang luas tentang hal-hal di sekitarnya.

\footnotetext{
${ }^{2}$ Quraish Shihab, Wawasan Al-Qur'an, Cet.XII (Bandung: Mizan, 2001), 394.
} 


\section{Berikan teladan yang baik}

Anak belajar dari orang-orang di sekitarnya, anak mengamati orang dewasa dalam kesehariannya dan akan meniru kebiasaannya. Maka, pastikan kita memberikan teladan yang baik pada anak sejak dini, baik dalam perkataan, perbuatan bahkan hal-hal kecil yang menjadi kebiasaan kita. Like a father like a soon, adalah ungkapan bagaimana anak adalah miniatur orangtuanya, anak adalah paste dari copyan orangtua dan lingkungannya, sehingga anak tidak hanya mewarisi hidung mancung, kulit putih dari orangtuanya, tetapi mewarisi kebiasaan orangtuanya. Maka idealnya, pola asuh yang benar dan konsisten harus dibudayakan dalam pendidikan anak.

3. Beri kebebasan bermain

Dunia anak adalah dunia bermain. Bermain adalah belajar bagi anak. Maka, jangan kita meremehkan aktivitas bermain pada anak. Karna dalam permainan itulah anak belajar dan mengembangkan kemampuannya. Maka, biarkan anak-anak kita bermain pasir, main air, lari-larian dan sebagainya, dengan tetap mengontrol aktivitas bermainnya. Ada banyak hal yang ia dapatkan dari bermain, diantaranya anak mengenal bahwa ia hidup berdampingan dengan ciptaan Allah yang lain, sehingga ia mulai menempatkan dirinya dengan keadaan lingkungannya, anak belajar menyelesaikan masalahnya dari hal-hal kecil dalam permainan, anak juga berlatih untuk berkomitmen dengan waktu ataupun aturan dalam permainan dan anak juga akan belajar arti kehidupan, menang kalah, jatuh bangun, sabar syukur, yang akan bermanfaat baginya di kemudian hari.

\section{B. Membaca bagi Anak Usia Dini}

Membaca dini ialah membaca yang diajarkan secara terprogram kepada anak prasekolah. Program ini menumpukkan perhatian pada perkataan-perkataan utuh, bermakna dalam konteks pribadi anak-anak dan bahan-bahan yang diberikan melaui permainan dan kegiatan yang menarik sebagai perantaraan pembelajaran (Steinberg, 1982: 54).

Membaca pada hakikatnya sudah dapat diajarkan pada balita, namun menurut penelitian Glen lebih efektif diberikan pada usia empat tahun daripada 
usia lima tahun. Bahkan, menurutnya usia tiga tahun lebih mudah daripada empat tahun. Jelasnya, makin kecil makin mudah untuk belajar, namun tentu semakin kecil usianya, akan sangat menuntut kesabaran pada orang tua atau guru yang mengajarkannya. Selanjutnya, Glen menjelaskan, mengajar membaca harus dimulai dengan mengeja, dimulai dengan pengenalan huruf kemudian mengenal suku kata, barulah mengenal kata dan akhirnya kalimat.

Menurut Tzu (1984:48) kesiapan membaca dini dapat diidentifikasi dari berbagai prilaku yang diperlihatkan anak, yaitu:

1. Rasa ingin tahu tentang benda-benda di dalam lingkungan, manusia, proses dan sebagainya

2. Mampu untuk menerjemahkan atau membaca gambar dengan menidentifikasi dan menggambarkannya

3. Menyeluruh dalam pembelajaran

4. Melalui kemampuan berkomunikasi dengan bahasa percakapan khususnya dengan kalimat

5. Memiliki kemampuan untuk membedakan persamaan dan perbedaan dalam suara secara cukup baik untuk mencocokkan atau suara lainnya

6. Keinginan untuk belajar membaca

7. Memiliki kematangan emosional yang cukup untuk dapat konsentrasi dan terus menerus dalam suatu tugas

8. Memilik percaya diri dan stabilitas emosi.

Menurut Gordon dan Brown (1985) dalam mengajarkan keterampilan membaca perlu dipersiapkan hal-hal yang berkaitan dengan perbendaharaan kata, keingintahuan anak tentang bacaan dan perbedaan visual dalam membelajarkan keterampilan membaca. Untuk lebih lengkapnya dapat dilihat pada tabel berikut: 


\section{Kesiapan Belajar Keterampilan Membaca Dihubungkan dengan Aktivitas yang Dipersiapkan Guru}

\begin{tabular}{|l|l|}
\hline READING READINESS IS & TEACHERS \\
\hline Oral vocabulary & $\begin{array}{l}\text { Encourage talking, learning new words and } \\
\text { phrases, singing finger play, remembering and } \\
\text { reflecting verbally }\end{array}$ \\
\hline Curiosty about/for reading & $\begin{array}{l}\text { Provide a separate are for books (and we } \\
\text { available to read to children), language games } \\
\text { (lotto) and dictation forms children (if Icould fly I } \\
\text { would...). Note about chidren that the children } \\
\text { deliver themselves to other adults }\end{array}$ \\
\hline $\begin{array}{l}\text { Auditory discrimination (the } \\
\text { ability to detect sound } \\
\text { differences }\end{array}$ & $\begin{array}{l}\text { Create sound discrimination boxed in the science } \\
\text { area, "listen to the sound" walk, guessing games } \\
\text { with musical instrument, activities that teach } \\
\text { letter sound by using the children's names }\end{array}$ \\
\hline Visual discrimination & $\begin{array}{l}\text { Support directionality, left and right (in the } \\
\text { "Hockey-Pokey" dance and labeled on shoes and } \\
\text { mittens), up and down, top and button, likeness } \\
\text { and differences }\end{array}$ \\
\hline
\end{tabular}

Sumber: Grown and Brown, 1985

Gordon dan Brown menyarankan agar sekolah memberikan berbagai kegiatan yang berkaitan dengan kesiapan membaca dan menulis, kegiatan tersebut yaitu:

1. Mengembangkan kemampuan berbicara dna mendengarkan, melalui percakapan, mendeskripsikan bahasa, memberikan balikan, dan kegiatan mendengarkan percakapan yang berarti;

2. Membantu anak mendengarkan fonem (suara bahasa) melalui kegiatan percakapan dalam permainan bahasa;

3. Memberikan banyak kesempatan kepada anak untuk membuat hubungan antara bahasa lisan dan bahasa tulis;

4. Memberikan penekanan dalam kegiatan membaca permulaan yang dilakukan oleh anak;

5. Mengisi lingkungan anak dengan kata-kata tertulis, agar anak menjadi lebih mengerti bahasa tulis;

6. Menggunakan bahasa yang jelas dan terang dalam pengajaran membaca. ${ }^{3}$

3 Ahmad Susanto, Perkembangan Anak Usia Dini, Cet.III, (Jakarta: Kencana Prenadamedia Group, 2014), 87. 


\section{Manfaat Membaca Bagi Anak Usia Dini}

Anak-anak yang sedari kecil terbiasa membaca - bukan sekedar membunyikan huruf dan kata - akan memiliki keterampilan, kemampuan dan ketajaman mencerna isi bacaan. Apa yang menggerakkan mereka membaca, akan sangat menetukan bagaimana mereka menyerap, menyaring, mengolah dan memaknai informasi yang mereka lahap dari berbagai bacaan. Semakin sering mereka membaca buku-buku yang bergizi, teratur dan baik penuturannya, kamampun berpikir mereka akan lebih matang dan tertata. Mereka memiliki kerangka berpikir yang kukuh dan rapi. Mereka juga mengembangkan kemampuan menimbang dan menila apa yang mereka serap dengan lebih baik.

Itu sebabnya, yang perlu kita kembangkan pada anak-anak kita semenjak awal bukan hanya kemampuan membaca. Pada saat yang sama, kita harus tanamkan nilai yang menjadi alas an dan penggerak bagi mereka. Kita tidak hanya menggerakkan mereka untuk memiliki kebiasaan iqra' semata. Lebih dari itu, mereka kita gerakkan untuk gila membaca sejak dini justru karena kita ingin menanamkan nilai-nilai keimanan dengan lebih kuat pada dada mereka. Kita tumbuhkan pada diri mereka semangat iqra' bismirabbikal ladzi khalaq. Bacalah dengan menyebut nama Tuhanmu yang menciptakan.

Ada tiga manfaat besar menumbuhkan kegilaan membaca pada anak-anak semenjak hari-hari pertama dilahirkan.

1. Merangsang terjadinya lompatan kecerdasan

Ada sebuah kisah menarik tentang manfaat membaca bagi anak sejak dini. Namanya Jennifer. Lahir pada September 1984 dari Rahim seorang ibu bernama Marcia Thomas. Ketika para ibu umumnya menyambut bayi dengan penuh rasa bahagia dan suka cita. Maria Thomas justru sebaliknya. Ada kecemasan ketika memandang anaknya. Jennifer tidak menampakkan tanda-tanda kehidupan yang wajar seperti lazimnya para bayi. Responnya lambat dan ekspresinya tampak lain.

Berdasarkan hasil pemeriksaan para ahli, Jennifer dinyatakan positif menderita down syndrome, suatu jenis keterbelakangan mental yang ditandai oleh rendahnya IQ sehingga tidak memungkinkan seseorang untuk hidup secara wajar. Tidak itu saja, pada usia dua bilan Jennifer hamper-hampir mengalami kebutaan, 
tuli dan keterbelakangan mental yang parah. Di usia yang masih sangat belia pula, Jennifer harus menjalani bedah korektif karena mengalami gangguan jantung.

Tetapi apa yang dilakukan Marcia? Terapi. Marcia memberikan kepada anaknya agar otaknya memperoleh rangsangan yang kaya, sehingga kecerdasannya meningkat dan fungsi-fungsi indranya bekerja lebih aktif. Marcia berusaha menjalankan proses terapi itu dengan sungguh-sungguh agar anaknya tidak mengalami keterbelakangan mental.

Caranya? Diet membaca! Marcia membacakan sebelas buku setiap hari kepada buah hatiya yang masih bayi. Hasilnya? IQ Jennifer melonjak tajam ketika dites pada usia empat tahun. IQnya seratus sebelas. ${ }^{4}$

Sehingga ini adalah salah satu alasan mengapa mengajarkan membaca pada bayi dapat melejitkan IQ adalah karena membaca merupakan kegiatan yang memberi rangsangan paling kompleks bagi otak dibandingkan beberapa kegiatan lainnya, melihat televisi misalnya.

2. Mematangkan emosi dan kepribadian

Manfaat pembelajaran membaca sejak dini ialah anak terbiasa berfikir menggunakan pengetahuan yang mereka miliki untuk memahami sekeliling. Anak mengembangkan rasa ingin tahu sekaligus kesabaran untuk memahami. Ia belajar untuk tidak tergesa-gesa. Ia juga belajar memahami segala sesuatu secara lebih teratur. Kita tidak bisa memahami isi bacaan secara keseluruhan kalau kita tidak membacanya dengan baik. Agar bisa membaca dengan baik, kita harus belajar mengendalikan diri, memusatkan perhatian, menghayati dengan perasaan, dan memahami makna tiap kata. Ini semua mematangkan emosi anak dan membangun kecakapan berpikir.

Tentu saja kematangan emosi yang benar-benar sempurna hanya bisa dicapai jika anak-anak dihadapkan pada tantangan. Tetapi, dasar-dasar kecakapan dan kematangan emosi, dipelajari dari buku-buku yang mereka cerna. Ketika anak menghadapi tantangan, ia menggunakan bahan-bahan yang tersedia di otaknya untuk mengelola emosi.

\footnotetext{
${ }^{4}$ Mohammad Fauzil Adhim, Possitive Parenting, (Yogyakarta: Pro-U Media, 2015), 77.
} 
Pertanyaannya, bahan-bahan apakah yang kita sajikan buat anak-anak kita? Bahan-bahan itulah yang akan sangat menentukan. Ia terekam kuat di pikiran anak kita. Meski kegiatan membaca itu sendiri memberi manfaat luar biasa bagi anak, bahan bacaan apa yang kita berikan pada anak tidak kalah pentingnya. Sayangnya, tidak setiap buku yang kelihatan bagus, benar-benar bermanfaat bagi anak. ${ }^{5}$

\section{Prinsip-Prinsip Pembelajaran Membaca Untuk Anak Usia Dini}

Prinsip pembelajaran membaca yang dimaksud disini ialah prinsip pembelajaran untuk menimbulkan kebiasaan dan minat membaca pada anak. Prinsip perlu diketahui terutama bagi tingkat dasae, agar anak memperoleh pengalaman belajar yang baik dan menyenangkan dalam belajar membaca tingkat dasar.

Mallquist (1971) menyatakan bahwa: Many research studies and ascertained that many children lack of success in the beginning stage of learning to read could be traced directly to inadequate or nonexistent reinforcement of expressive and receptive language skilis in the early, formative years.

Sesuai dengan pendapat Mallquist tersebut, maka pembelajaran membaca di taman kanak-kanak harus benar-beanar dilaksanakan dengan sistematis, artinya sesuai dengan kebutuhan, minat, perkembangan dan karakteritik anak. Proses pembeajaran, alat-alat permainan (media pembelajaran) yang digunakan, harus memerhatikan hal ini dan lingkungan belajar harus kondusif. Hal ini sangat penting, sebab bila anak mengalami kegagalan pada periode ini, akan berpengaruh terhadap kemampuan berbahasa anak, baik keterampilan ekspresif maupun reseptif.

Torrey (1979) mengemukakan empat prinsip pembelajaran membaca untuk anak. Prinsip-prinsip ini yaitu:

First, they have tried to provide external stimuli that would attract attention and interest to appropriate material and make possible guide discovery principles. Second, ini every case the meaning of written material has been

\footnotetext{
${ }^{5}$ Ibid., 79.
} 
emphasized as much as possible and as early as possible. Third, it is has been a policy in all this attempts to avoid coercion. Younger children have been given a free choice whether to learn reading it all, so that those who learned could be said to have done it on their own initiative even though they were in training situation. Finally, systematic attempts have been to keep to keep the children active rather than passively receptive.

Salah satu prinsip yang dikemukakan oleh Torrey tersebut ialah bagaimana agar anak tertarik dalam kegiatan membaca, sehingga kegiatan ini menjadi kegiatan yang menyenangkan. Jika anak sudah memiliki rasa senang membaca, akan lebih mudah untuk dibimbing dalam kegiatan belajar membaca yang lebih kompleks. Kegemaran membaca ini akan lebih tepat bula sudah ditanamkan sejak dini, sehingga kegiatan membaca bukan menjadi suatu beban, melainkan suatu kebutuhan. ${ }^{6}$

\section{E. PERKEMBANGAN KEMAMPUAN MEMBACA PADA ANAK USIA DINI}

Menurut Steinberg (1982:28) mengatakan bahwa, kemampuan membaca anak usia dini dapat dibagi atas empat tahap perkembangan yaitu:

1. Tahap timbulnya kesadaran terhadap tulisan

Pada tahap ini, anak mulai belajar menggunakan buku dan menyadari bahwa buku ini penting, melihat dan membalik-balikkan buku dan kadang-kadang ia membawa buku kesukaannya.

2. Tahap membaca gambar

Anak usia taman kanak-kanak telah dapat memandang dirinya sebagai pembaca dan mulai melibatkan diri dalam kegiatan membaca, pura-pura membaca buku, memberi makna gambar, menggunakan bahasa buku walaupun tidak cocok dengan tulisannya. Anak sudah menyadari bahwa buku memiliki karakteristik khusus, seperti judul, halaman, huruf, kata dan kalimat, serta tanda baca. Anak sudah menyadari bahwa buku terdiri dari bagian depan, tengah dan bagian akhir.

\footnotetext{
${ }^{6}$ Susanto, Perkembangan Anak Usia Dini, 89.
} 
3. Tahap pengenalan bacaan

Pada tahap ini, anak usia taman kanak-kanak telah dapat menggunakan tiga system bahasa, seperti fonem (bunyi hurf), semantic (arti kata) dan sintaksis (aturan kata atau kalimat) secara bersama-sama. Anak yang sudah tertarik pada bahan bacaan mulai mengingat kembli cetakan hurufnya dan konteksnya. Anak mulai mengenal tanda-tanda yang ada pada benda-benda di lingkungannya.

4. Tahap membaca lancar

Pada tahap ini, anak sudah dapat membaca lancer berbagai jenis buku yang berbeda dan bahan-bahan yang langsung berhubungan dengan kehidupan seharihari. $^{7}$

\section{F. Pembelajaran Membaca Al-Qur'an pada Anak}

Sebagai orangtua, kita tak ubahnya seorang guru yang mengajarkan banyak hal kepada anak. Kita pulalah yang seharusnya pertama-tama mengenalkannya membaca, menulis dan aneka macam ilmu pengetahuan serta wawasan keagamaan.

Bila semua pengetahuan ditransfer ke anak, maka Al-Qur'anlah yang seharusnya menjadi referensi pertama dan utama orangtua. Kalau semua buku yang diperkenalkan dan dibacakan kepada anak, maka Al-Qur'anlah yang seyogyanya menjadi buku paling favorit baginya. Dari semua huruf yang kita ajarkan, hendaklah ia dimulai dari huruf alif.

Beberapa penelitian meyebutkan bagaimana lantunan ayat-ayat Al-Qur'an membantu perkembangan otak bayi meskipun ia masih berada dalam kandungan ibunya. Tidaklah mengherankan jika tak sedikit anak berusia belia sudah fasih menghafalkan ayat-ayat Al-Qur'an karena begitu seringnya orangtua memperdengarkan dan membackan kepadanya. ${ }^{8}$

Tentunya dalam mengajarkan Al-Qur'an pada anak dimulai dengan sesuatu yang mudah, mengikuti perkembangan atau kemampuan anak. Dan agar

\footnotetext{
${ }^{7}$ Ibid., 90.

${ }^{8}$ Mayyadah, Inspirasi Parenting dari Al-Qur'an, (Jakarta:PT Alex Media Komputindo
} Kompas-Gramedia, 2016), 151. 
anak tidak terbebani atau merasa berat dalam belajar Al-Qur'an. Dalam Q.S. Al Muzammil: 20, Allah berfirman:

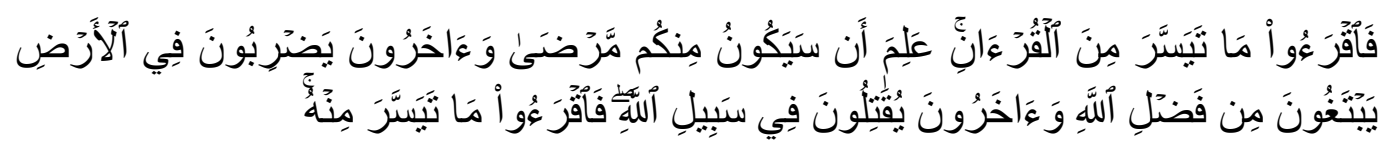

Terjemahnya:

bacalah apa yang mudah (bagimu) dari Al-Qur'an. Dia mengetahui bahwa akan ada di antara kamu orang-orang yang sakit dan orang-orang yang berjalan di muka bumi mencari sebagian karunia Allah; dan orang-orang yang lain lagi berperang di jalan Allah, maka bacalah apa yang mudah (bagimu) dari Al-Qur'an. (Q.S. Al Muzammil:20)

Beberapa prinsip dalam mengajarkan Al-Qur'an pada anak:

1. Jangan hanya mengajarkan anak untuk membaca Al-Qur'an, tetapi juga usahakan agar anak memahami makna dan hikmah-hikmah dari ayat yang diajarkan kepadanya. Buatlah aktivitas tadabbur Al-Qur'an dan ajak anak berdiskusi. Perkenalkan ia kisah-kisah menarik dalam Al-Qur'an yang menjadikan anak-anak semakin tertarik belajar Al-Qur'an.

2. Mulailah dengan ayat-ayat atau surah-surah pendek untuk memudahkan anak menghafalkannya, jangan memaksakan anak menghafal ayat-ayat yang terlalu panjang jika ia belum mapu. Saat anak belajar salat, maka orangtua membimbing anak untuk membaca suraj-surah pendek sehingga otomatis anak akan menghafal dan mengingatnya. Usahakan bahwa keinginan menghafal AlQur'an datang sendiri dari dalam dirinya, bukan karena ambisi orangtua semata.

3. Jika anak masih merasa kesulitan, maka perbanyaklah memperdengarkan ia lantunan tartil Al-Qur'an agar telinganya terbiasa dengan kalimat-kalimat Allah sehingga ia tidak merasa asing dengan ayat-ayat Al-Qur'an. Saat tartil Al-Qur'an dikumandangkan, maka seluruh penghuni rumah hendaknya tidak melakukan aktivitas yang bertentangan dengan kesucian Al-Qur'an seperti menyalakan televisi, menyetel musik atau berbicara hal-hal yang sia-sia.

4. Jika anak masih enggan belajar Al-Qur'an, maka orangtua hendaklah memperbanyak membacakan Al-Qur'an dengan meniatkannya sebagai obat pencair kerasnya hati anak. Bacakanlah surah Al-Fatihah atau surah Al-Insyirah 
dan usaplah kepalanya. Bacakan setiap menjelang anak tidur dengan harapan agar Allah membuka hati anak untuk mau dan cinta belajar Al-Qur'an. Anak-anak pecinta Al-Qur'an akan lahir dari rumah yang cinta Al-Qur'an pula, maka ciptakanlah keteladanan yang dimulai dari orangtua. ${ }^{9}$

\section{KESIMPULAN}

Iqra' bukanlah sekedar ayat yang dibaca dalam Al-Qur'an, tetapi iqra' adalah sebuah pintu pengetahuan dan peradaban, dari iqra'lah anak mengenal dunianya, dari iqra'lah anak mengenal Tuhannya, dari iqra'lah anak mengenal bagimana seni hidup di muka bumi ini. Maka, peran orangtua dan guru PAUD sangat dibutuhkan dalam menstimulus anak mengembangkan kemampuannya melalui iqra' yaitu membaca. Membaca yang tidak diartikan sempit seperti mengenal huruf, mengeja dan membaca kumpulan huruf dan kalimat, tetapi juga membaca alam dan kejadian di sekelilingnya sebagai bahan pengetahuan dan pengalamannya yang menjadikan anak belajar dari segala hal di sekelilingnya yang kemudia $\mathrm{n}$ mengantarkan sang anak menjadi manusia yang beriman dan berwawasan luas.

Membaca pada anak tentunya bukan hal yang wajib dimulai di usianya yang dini. Tetapi selayaknya, anak perlu ditanamkan dan ditumbuhkan kesenangan terhadap buku dan bacaan dengan menghadirkan buku-buku yang penuh dengan gambar dan warna yang menarik perhatian anak, terlebih lagi mengenalkan anak dengan Al-Qur'an. Sehingga anak tumbuh dengan kecintaan terhadap buku dan Al-Qur'an, yang kemudian berkembang menjadi sebuah kebiasaan dan kebutuhan dalam hidupnya kelak, yaitu membaca dan membaca.

\footnotetext{
${ }^{9}$ Ibid., 156.
} 
310 | MUSA WA, Vol. 12 No.2 Desember 2020 : 297-310

\section{DAFTAR PUSTAKA}

Adhim, Mohammad Fauzil. Possitive Parenting. Yogyakarta: Pro-U Media, 2015.

Mayyadah. Inspirasi Parenting dari Al-Qur'an. Jakarta:PT Alex Media Komputindo Kompas-Gramedia, 2016.

Shihab, Quraish. Tafsir Al-Misbah. XV. Jakarta: Lentera Hati, 2012.

Shihab, Quraish. Wawasan Al-Qur'an. Cet.XII. Bandung: Mizan, 2001.

Susanto, Ahmad. Perkembangan Anak Usia Dini. Cet.III. Jakarta: Kencana Prenadamedia Group, 2014. 